\title{
Immigration Standards After the War
}

\section{By Henry Pratt Fairchild}

$\mathrm{O}^{\mathrm{N}}$ NE of the knottiest problems which will have to be faced in the establishment of a world state or a league of nations will be the question of the movement of people. Under the national economy which has prevailed hitherto, every state has assumed its own right to determine what should be the constituents of its population so far as extrinsic contributions were concernedin other words, the right to control immigration-and few states, with the exception of Japan, have questioned the legal or moral right of other states to make such a determination. On the other hand, few modern states have found it expedient to place limitations upon the movements of their own people within their own territory.

Whether the era of internationalism which is now dawning results in the formation of a world state, or in a more loosly coordinated league or federation of self-determining units, in either case there can be only two general alternatives as regards migrations. Either there will be a free right of passage over the entire territory included in the state domain, analogous to the present right of travel within a given country, or else restrictions must be placed by the central authority, or by the federated states in accordance with a common agreement and consent, with respect to boundaries broadly similar to those which now separate existing nations. In the former case, there would be introduced the new principle of discrimination within a given jurisdiction; in the latter, the way would be left open to unpredictable bitterness, jealousy and dissension. Either solution is full of uncertainties and dangers.

It is the purpose of this paper to show that, great as are the difficulties of migration control under a world government, for the present the scientific and only safe course is to insist upon restrictions (so far as the United States, at least, is concerned) at least as rigorous as those which were in operation before the outbreak of the war. The demonstration of such a proposition calls for a matter-of-fact, impersonal analysis which seems at 
first to ignore the claims of humanitarianism and universal brotherhood, and yet is as fully legitimate as if the subject under discussion were the transplantation of fruit trees, or the control of river currents.

The ultimate goal of the present convulsion, the military phases of which have happily terminated, and the political and social phases of which have just begun, is the establishment of universal democracy. Democracy is composed of various elements, and is difficult of definition or description. But of its material elements there is no better embodiment and criterion than the standard of living of the common people. Where the standard of living of the people is high, relative to the general producing power of their territory, there democracy flourishes, by whatever name the government may be called. Where the masses live on a low plane of comfort, democracy languishes and dies, however great may be the tabulated wealth of that nation. Speaking of the world at large, if a higher standard does not result for the great bulk of mankind, all this blood will have been shed largely in vain. If there should result a general lowering of the standard over the entire globe it would be an unspeakable calamity, dwarfing all the untold horrors and losses of the conflict itself.

For the remainder of this discussion, let us lay to one side all question of the inferiority and superiority of racial stocks, and think only of the tangible values of material comfort and spiritual welfare, about which there can hardly be a difference of opinion. What is the obligation of the United States with reference to maintaining, and if possible raising, the standard of living of the great masses of mankind, of whatever race or affiliation?

The naive answer to this question might easily be that our duty is to share our blessings as liberally and impartially as may be with all those who care to participate in them, all the more so, since our losses in defense of democracy have been so trivial in comparison with those of our gallant Allies who have borne the burden of the conflict. If there were, before the war, hosts of conscientious, intelligent people who were ready to throw our doors wide open to "the down-trodden and oppressed of every land," there will be more now who will conceive it as the acme of national selfishness if we refuse asylum to the would-be refu- 
gees who will seek to escape the drudgery and hardships of the reconstruction period in Europe.

Let us set down certain basic considerations bearing upon the question, with reference to which there will be general agreement and which will clarify the more dubious steps of the argument. In the first place, there is little doubt that before the war the people of the United States enjoyed a higher standard of living than any other considerable nation. This was ours, not because of any special merit of our own, but because of the peculiarly fortunate conjunction of land, climate and historical development which has given us an unparallelled command over the sources of wealth. Our standard is rather in the nature of a free gift than an achievement. In the second place, it will hardly be denied that if the spirit of universal brotherhood is to dominate the world, those of us who have been fortunate enough to have our lot cast in this bountiful land must not seek to monopolize these blessings entirely for ourselves, just because we happen to be now in possession of them, or because the nation of which we are the constituent parts has "owned" them for a century and a half. Surely the modern thing, the altruistic thing, the post-magnum-bellum thing to do is to share these benefits as unreservedly as possible, particularly with those suffering peoples with whom we have been so closely associated during a year and a half of war. The crucial question is whether or not we can best share them by allowing the individual representatives of those and other peoples free access to the land from which we draw our wealth and power.

No space need be devoted to a portrayal of the dire conditions which would result if large contingents of foreign labor should be admitted to this country within two or three yearsfrom the present date. It is painfully obvious that we shall have all that we can do to handle the problems of demobilization of our own army, and readjustment of our industrial situation, without serious injury to our standards of wages and working conditions. Such an immigration as was normal during a busy year before the war would now be an intolerably complicating factor. Probably this will be prevented without any direct action by the use of shipping for other purposes, and other contributory forces. But if it should transpire that the current of immigrant labor began to flow once more while our army was still being demobilized, such a current 
should certainly be checked by effective means, however drastic. The larger problem, however, has to do with the effects which may be expected to follow the resumption of immigration when peace conditions are measurably restored.

Modern immigration, as is recognized by all authorities, is largely an economic phenomenon, that is, it represents a search for a higher standard of living. Almost without exception, the countries which furnish large bodies of immigrants to the United States have a standard lower than ours, or at least the classes which emigrate have a lower standard than similar classes in this country. More than that, our general standard is so much higher than that of most foreign countries that our lowest economic classes have a standard above that of much higher classes in other lands. Immigration, therefore, represents the introduction of lower standards into a country of higher standards.

The immigration of foreign labor to the United States tends to lower the standard of living of our working classes. It numerically increases the supply of workers bidding for employment and therefore tends to lower the prevailing wage or at best prevent it from rising. This is a sufficiently serious influence, but if the immigrants were habituated to the same standard as the natives, so that the effect was exclusively numerical, the result would not be necessarily calamitous, especially in times of expanding industry when immigrants come most freely. Immigration, however, has an influence much more powerful and much more disastrous, that is directly connected with the standard of living itself.

The introduction of a relatively small contingent of foreign labor into an industrial country may have a depressing effect upon the standard of living of the working people in that country out of all proportion to the numbers involved, provided that the immigrants are accustomed to a definitely lower standard than the natives. The process may be schematically described as follows: Suppose that there is in the United States an industrial town centering about one great plant which is the economic backbone of the community. Suppose that this plant employs 10,000 people, the bulk of the wage-earners of the town. These workers are reasonably efficient, and receive wages sufficient to enable them to maintain their families in a fair degree of comfort. Say that the aver- 
age daily wage runs about $\$ 3.00$. Into this town there comes some morning a group of 500 raw immigrants in charge of a labor importer. These foreigners are men not materially inferior in economic productiveness to the natives of the town. But they have previously lived in a country where the conditions of existence are so much inferior that their customary wage is the equivalent of only $\$ 1.50$ of American money. To receive a wage of $\$ 2.00$ a day would therefore enable them to raise their standard very decidedly, and they will snatch at the chance to work for such a wage. Immediately upon their arrival, the labor agent goes to the superintendent of the plant and offers him 500 laborers at $\$ 2.00$ apiece. The superintendent looks them over, becomes convinced that they can do the work approximately as well as his present workers and agrees to take them on. He then calls in his foremen, and together they select the 500 least efficient of the $\$ 3.00$ men, who are thereupon informed that they are to be discharged. Upon learning the reason, they protest that they have their homes and families in the town, they do not know where else to find employment, and rather than lose their jobs altogether they will accept the wage offered to the foreigners. With a show of generosity, the superintendent offers to pay them $\$ 2.25$ a day, and they go back to their places. In the meantime the group of foreigners are still available. Therefore the next most inefficient group of 500 employes is selected, and the process repeated, with the same result. So it goes on, until eventually every one of the 10,000 original workers has had his pay reduced by fifty or seventy-five cents. At the same time, not one of the immigrants has been employed, and in the evening the group departs to try its luck elsewhere.

It goes without saying that in the complicated life of the nation at large the process does not go on so simply and mechanically as this. But exactly this principle is at work, however much its operation may be masked by contributory forces. There can be no doubt that the competition of laborers habituated to a lower standard is the most pernicious and insidious force which can attack the standard of living of the workers of a modern industrial democracy. It has been well stated that there is a Gresham's law in the industrial world, whereby the poorer labor drives out, the better, and the lower standard eliminates the higher. 
There can be no question that free immigration of foreign labor thoroughly undermines the standards of our common people. The process was already beginning to tell disastrously before the war, and would be immeasurably augmented if immigration should again go on unchecked, now that there will be so much added incentive for the tax-burdened natives of European countries to seek this land.

The worst of the whole matter is that there is no limit to the process. The drawing off of a sufficient number of laborers from such countries as India and China to destroy our own standard would produce no appreciable benefit in those countries, for the simple reason that it would not reduce the pressure of population there, and therefore could not raise their standard. A million immigrants a year perpetually could easily be drawn from China without decreasing its population in the least. The logical outcome of free immigration of workingmen under modern conditions of competitive bargaining for labor, as General Walker pointed out long ago, is the reduction of the standard of living of all countries to one dead level, and that the level of the originally most degraded and backward of them all.

It needs no argument to show that the United States is not called upon to sacrifice her standard for the sake of mere unreasoning sentimentality. She would be most recreant to her trust if she did so. Standards of living once lost can hardly be regained. It is our duty as a nation, our duty to humanity in the highest sense of the word, to protect our standard, in order that it may serve as a model and goal for the striving democracies in other lands, and that we ourselves may be in a position to help those democracies to climb somewhere near to the plane of their ideals.

The question of immigration after the war is often stated as the problem of whether we need to protect ourselves against the dumping of cripples and incompetents from foreign sources. The real question is, how we may protect ourselves from the ablebodied workers of less fortunate lands. Paradoxical as it may seem, we have much less to fear from the man who cannot earn his living than from the man who can. This is a rich country, and we could well afford to support for the rest of their lives thousands of the physical wrecks of war from England, France, Belgium, Italy, Greece, Russia and Serbia. It would be but a slight recog- 
nition of our debt to those countries who have paid so much dearer for the liberty of the world than we have if our military hospitals and cantonments were gradually transformed into homes for as many disabled victims as our Allies chose to send us (under proper government supervision to prevent abuse), while we taxed ourselves liberally for their lifelong support and comfort. This would cost us nothing but money. But to permit the free transference of the labor from those countries to this under conditions which meant the disruption of our own standards would cost us our very life, and worst of all, would cost us our ability to be of real and permanent help to less fortunate lands.

The foregoing discussion rests upon the assumption that in general the present economic system will prevail,-private ownership of capital, competitive wage-bargaining, individual responsibility for family living conditions, etc. What might happen under conditions of socialism, or a world-wide minimum wage is merely matter for conjecture-except that it is hard to conceive of any minimum wage which would not speedily break down under conditions of free immigration. 